\title{
Hemoglobin E-beta-thalassemia syndrome
}

INSERM

\section{Source}

INSERM. (1999). Orphanet: an online rare disease and orphan drug data base.

Hemoglobin E-beta-thalassemia syndrome. ORPHA:231249

Hemoglobin E - beta-thalassemia ( $\mathrm{HbE}-\mathrm{BT}$ ) is a form of beta-thalassemia (see this term) that results in a mild to severe clinical presentation ranging from a condition indisting uishable from beta-thalassemia major to a mild form of beta-thalassemia intermedia (see these terms). 